\title{
Research advances on climate-induced slope instability in glacier and permafrost high-mountain environments
}

\author{
Christian Huggel, Luzia Fischer, Demian Schneider, \\ Wilfried Haeberli, Zürich
}

\section{Introduction}

Rapid changes in glacierized high-mountain regions due to atmospheric warming are increasingly destabilizing bedrock and debris slopes, as well as steep glaciers (Evans \& Clague 1994; Gruber \& Haeberli 2007; Haeberli et al. 1997; Huggel 2009). Degrading permafrost can affect bedrock stability while warmer temperatures with more intense and longer melting conditions can contribute to failures of steep glaciers. In many cases, glaciers and permafrost on steep slopes are closely interrelated and must be considered in combination (Fischer et al. 2006; GrUber \& HAEBERLI 2007; HaEBERLi 2005; KäÄB et al. 2005). Their coupling through the hydrological and thermo-mechanical systems are, however, complex and far from being sufficiently understood.

Recent rapid mass movements in the Alps and in other mountain regions involving large volumes of ice and rock (Fig. 1) might already be related to climate induced changes in slope stability (FISCHER 2009; Gruber \& Haeberli 2007; Huggel 2009). Examples are the $2.5 \times 10^{6} \mathrm{~m}^{3}$ rock avalanche from Punta Thurwieser, Italy, in 2004 (Cola 2005), the 2-3 x $10^{6} \mathrm{~m}^{3}$ Brenva rock-ice avalanche, Mont Blanc region, Italy, in 1997 (BARLA et al. 2000), the $<1 \times 10^{6} \mathrm{~m}^{3}$ rock slides from Dents du Midi and Dents Blanches, Switzerland, in 2006, and the rock avalanche from Monte Rosa east face, Italy, in 2007 (Fig. 1). All these rock slope failures initiated from relatively warm permafrost areas. Similarly, in the Mont Blanc area it appears that a majority of recent rock falls with volumes between 100 and $50,000 \mathrm{~m}^{3}$ also originated from warm permafrost areas (RAVANEl et al. 2010). In 2005, a large ice avalanche, also from Monte Rosa east face, involved more than one million $\mathrm{m}^{3}$ of ice (FIscher et al. 2006; HugGel 2009). Historical precedence of these events at the same sites and of similar magnitude is not known. Repeated ice avalanches from the northeast face of Weisshorn (Switzerland), that have been observed five times in the last three decades (FAILlettaz et al.2008), however, are probably related to periodic build-up and failure cycles of hanging glaciers.

In this context it is important to distinguish between processes that gradually decrease slope stability over time scales of decades to millennia, and those that can act as triggers of slope failures within short time scales up to several days. Secular and decadal warming degrades permafrost (Noetzli et al. 2007; Noetzli \& Gruber 2009 ) or results in glacier retreat that may decrease slope stability (e.g. OPPIKOFER et al. 2008). Examples for triggers of large slope failures, on the other hand, are earthquakes within seconds (JIBSON et al. 2006; KEEFER 2002), rainfall within hours (WIECZOREK \& GLADE 2005; ZIMMERMANN et al.1997) or extreme temperature events within days or weeks (HugGEL et al. 2008).

Densely populated and highly developed mountain areas, such as the Swiss Alps, are particularly prone to hazards from rapid mass movements. It is therefore important to improve and develop appropriate methods for process understanding, monitoring, early warning and prevention. Switzerland, in fact, has developed a long tradition in research, assessment, monitoring and management of corresponding glacier and permafrost hazards, because it has been notoriously exposed to such events (HAEberLI et al. 1989, 2006; Pralong \& FUNK 2005). Several Swiss research groups have made important contributions in this field in the last years. This article presents some advances that have recently been achieved in research projects that include both the investigation of the failure conditions and the mobility of rapid mass movements, and that range from local-scale to regional-scale applications.

\section{Investigations on failure processes}

To assess the hazards associated with ice, rock and combined rock-ice avalanches it is useful to distinguish between processes that relate to the failure and initiation mechanisms, and those referring to the dynamic propagation and runout of the events. For ice avalanches classifications of failure types have been developed and revised over the past decades (AlEan 1985; Haefeli 1966; Pralong \& FunK 2005) and generally describe the break-off conditions and processes. The understanding of the controls on the failure processes is fundamental for the assessment of the related hazards but is currently still incomplete. Rock slope failures can be classified in rock fall, topple, slide, flow and complex slides involving several mechanisms (Cruden \& Varnes 1996). Identification of the exact failure mode is often difficult, as it depends strongly on the structural geology, whereof data is often lacking in remote high-mountain areas. 


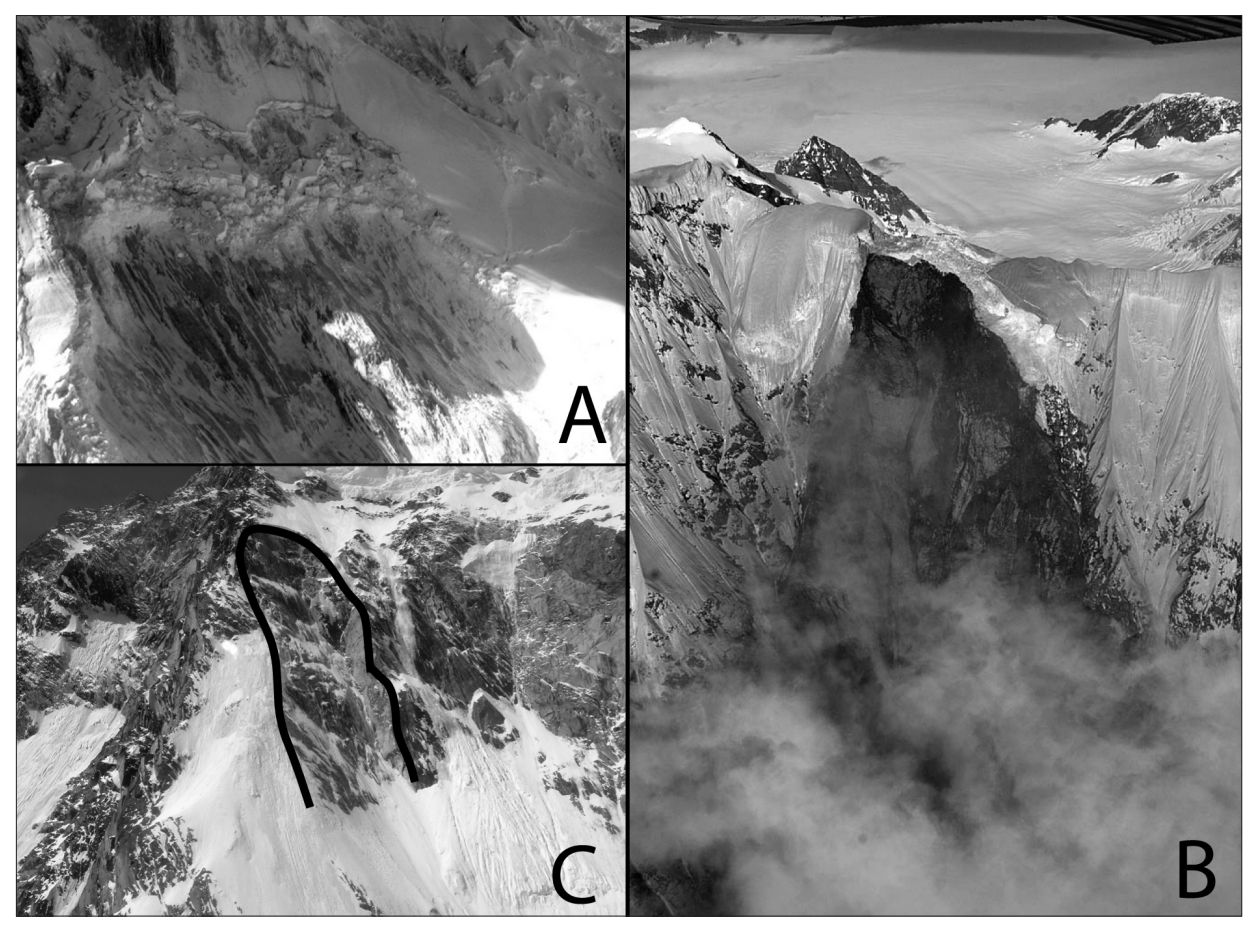

Fig. 1: Initiation zones of three types of rock-ice avalanches from glacier and permafrost environments: A: a classic example of a large ramp or slab-type ice avalanche that occurred in 2004 from Iliamna volcano, Alaska (avalanche total volume 4-6 million $\mathrm{m}^{3}$ ); B: failure zone of a combined rock/ice avalanche from Mt. Steller, Alaska, in 2005 (total volume $\sim 50$ million $\left.\mathrm{m}^{3}\right)$; C: a rock slope failure in high elevation ( 4000 $\mathrm{m}$ a.s.l.) in the Monte Rosa east face that occurred during the exceptionally hot April 2007 (total volume 0.3 million $\mathrm{m}^{3}$ ).

Anrisszoneen von drei Typen von Fels-Eislawinen in Gletscher- und Permafrost-Gebieten: A: ein klassisches Beispiel eines grossen Rampenanrisses einer Eislawine, die sich 2004 am Iliamna Vulkan in Alaska ereignete (Lawinenvolumen 4-6 Mio m³); B: Anrisszone einer kombinierten Fels-Eislawine am Mt. Steller (Alaska) 2005 (Lawinenvolumen $\sim 50$ Mio $\left.\mathrm{m}^{3}\right)$; C: ein Felssturz aus grosser Höhe ( 4000 m ü.M.) der Ostwand des Monte Rosa, der sich im aussergewöhnlich heissen April 2007 ereignete (Volumen $0.3 \mathrm{Mio} \mathrm{m}^{3}$ ).

Zones de détachement de trois types d'avalanches de glace et de rochers en provenance d'environnements glaciaires et de permafrost. A: un exemple classique d'une grande avalanche glaciaire sur rampe ou dalle qui s'est déroulée en 2004 depuis le volcan Illiamna en Alaska (volume total de 4 à 6 millions de $m^{3}$ ). B: zone de cassure d'une avalanche combinée glace-rochers venant du Mont Steller en Alaska en 2005 (volume total d'environ 50 millions de $\left.\mathrm{m}^{3}\right)$. C: cassure sur une pente à haute altitude (environ $4000 \mathrm{~m}$ ) sur la face est du Mont Rose qui s'est déroulée durant le mois exceptionnellement chaud d'avril 2007 (volume total de 0,3 million de $\mathrm{m}^{3}$ ).

Photos: J. Caplan-Auerbach, R. Homberger, C. Huggel

Early detection and realistic anticipation of potential instabilities and related hazard potentials under conditions of complex high-mountain topography with correspondingly high variability of local conditions, therefore, remain the primary research challenge for the future. Accordingly, the question whether and how the recent and future climatic changes will affect the stability of glaciers and bedrock has only been addressed in a few recent studies, which leave a number of issues in this respect open (BOTTINO et al. 2002; FisCHER 2009; Gruber \& Haeberli 2007; Haeberli et al. 1997; HugGel et al. 2008; KäÄB et al. 2005).

Steep glaciers and steep bedrock flanks typically are in delicate stability conditions influenced by a number of factors, including e.g. topography, bedrock geology, ice and bedrock temperature and hydrology. Changes in one of these factors may lead to instability and failure. 
For rock slopes in glacier and permafrost environments a concept of interacting factors has been proposed by Fischer \& Huggel (2008). Topographic changes in steep glacierized high-mountain walls are often linked to mass movement activity, including both frequent low-magnitude processes and rare large-magnitude events. Monitoring of topographic changes can provide important insights into failure processes and dynamics. However, the extreme conditions of such environments make on-site measurements difficult. Photogrammetry based analyses could reconstruct changes of the hanging glacier in the Eiger west face (КёӒв 1996). In recent years, LIDAR (Light Detection And Ranging) technique has rapidly advanced, including both terrestrial and airborne (from helicopter or fixed-wing aircrafts) measurements to generate high-resolution digital terrain data (CHEN et al. 2006; OPPIKOFER et al. 2008). In a pilot study in the Monte Rosa east face a helicopter based LIDAR campaign was conducted in September 2007 (University of Zurich and Helimap). Scanning a high-mountain wall of the dimension of the Monte Rosa east face (ca. $2500 \mathrm{~m}$ high) is a technical challenge due to local meteorological conditions, limitations of the availability of receiving GPS (Global Positioning System) satellites and required high skills of the helicopter pilot. Technically somewhat less difficult are LIDAR measurements from fixed-wing aircrafts. The LIDAR derived DEM (Digital Elevation Model) of the 2007 campaign was compared to a LIDAR DEM from a 2005 fixed-wing overflight by swissphoto, and additional DEMs produced from high-precision photogrammetry using air photos from 1956, 1988 and 2001 (Fig. 2; FISCHER 2009).

The obtained results are an unprecedented documentation of topographic changes of a large glacierized mountain wall over half a century. The spatial resolution is on the order of 2-5 m with an accuracy of about 0.5-2 m. DEM-derived information alone may be difficult for interpretation in terms of processes; combination with oblique and vertical photography is therefore an important complement. The study shows that periods of relatively low mass movement activity between the 1950s and 1980s have been followed by much more dramatic changes, in particular in the 1990s. Mass changes involved major failures in bedrock and glacier ice. Continuous mass movements were accompanied by large single events, such as the August 2005 ice avalanche (>1 million $\mathrm{m}^{3}$; Fig. 2) and the April 2007 rock avalanche (ca. $300,000 \mathrm{~m}^{3}$; Fig. 1C).

The mechanisms that caused the massive slope failures are not yet understood in detail. For the 2007 Monte Rosa rock avalanche the large topographic changes due to slope failures and glacier retreat in the preceding years and decades, and related reduced support at the base of the slopes, resulting in stress changes, were important factors for the failures (FISCHER et al. 2006; FISCHER et al.). Rising temperatures since the 1980s thereby coincide with enhanced slope instabilities at Monte Rosa.

Although difficult to detect at specific cases, rising air temperatures can have an influence on the stability of steep glaciers. Latent heat effects from refreezing of percolating melt water can lead to a non-linear increase of the firn and ice temperature (Huggel 2009; Suter 2002). An upward shift of firn facies zones, from the percolation zone to the wet snow and eventually the temperate zone, implies an extension of melting both in time and space. An increase of the firn and ice temperature, along with an increase of melt water can then reduce the shear strength at the bedrock/ice-interface of steep glaciers and possibly result in failure.

Complex failures in both bedrock and ice have been observed on several occasions in recent years, e.g. in the European Alps, Alaska, New Zealand and the Caucasus (Allen et al.; HaEberli et al. 2004; Huggel et al. 2008). It has thereby been proposed that thermal interactions between steep glacier ice and surrounding bedrock and related effects on the hydraulic and eventually stress regime can exert an influence on slope stability (HAeBerli et al. 2004; Huggel 2009).

However, the incomplete understanding of the failure process makes the assessment and prediction of potential rock-ice avalanches difficult. Spatial modelling of critical factor combinations and long-term visual observation may help with recognizing serious hazard potentials and with establishing adequate monitoring at the right places and in the right time (Diotri et al. 2009; RöTHLisberger 1987). The application of multi-technique approaches can thereby be important. LIDAR campaigns such as described above can be performed regularly for critical areas but are expensive and laborious for larger regions. While these techniques are typically applied months, weeks or days before failure, recent studies using seismic signals may support immediate early warning in the future. In Alaska, where rock-ice avalanches in the order of tens of millions cubic meters periodically occur on Iliamna volcano, it has been revealed that failures in ice exhibited a sequence of small precursory earthquakes (CAplan-Auerbach \& Huggel 2007). These signals start between one and a half to two hours before the avalanche and have so far only been observed in failures of ice. If such precursory seismic signals can one day be analyzed in real-time and unambiguously recognized as onset failure processes, they could in fact be an important tool for early warning of ice avalanches. On Weisshorn and Mönch hanging glaciers, Switzerland, geophone measurements indicated that the seismic activity strongly increased three days before 


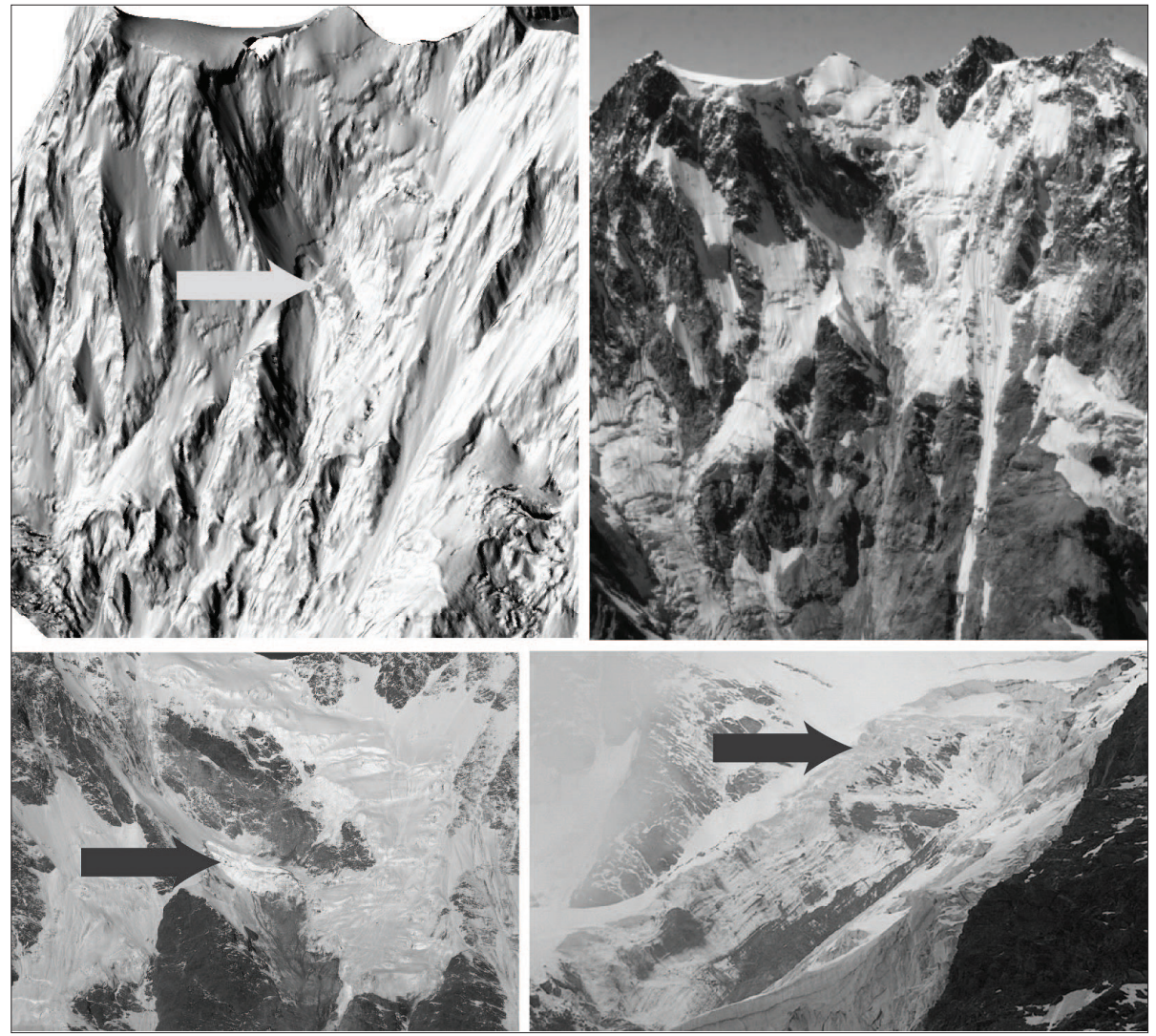

Fig. 2: Shaded relief of the 2005 LIDAR DEM of the Monte Rosa east face in 2005 (upper left) showing detailed topographic features, and a photographic overview of the east face (upper right, 2007). The arrows in the shaded relief and the lower two photographs mark the detachment zone of the large ice avalanche in 2005. The width of the failure zone is about $120 \mathrm{~m}$ across, thickness of detached glacier is 15 to $30 \mathrm{~m}$. Both large terrain changes and smaller features can be identified and quantitatively assessed using LIDAR.

Schattiertes Relief des 2005 LIDAR DEM der Monte Rosa-Ostwand (oben links) mit einem hohen topographischen Detailgrad und entsprechendes Übersichtsfoto der Ostwand (oben rechts, 2007). Die Pfeile deuten jeweils die Anrisszone der grossen Eislawine von 2005 an. Die Breite der Anrisszone misst 120 m mit einer Eisdicke von 15-30 m. LIDAR-Daten werden zur Erkennung von sowohl grossen wie kleinen topographischen Veränderungen benutzt.

Relief ombré du 2005 LIDAR DEM de la face est du Mont Rose en 2005 (en haut à gauche), montrant des caractéristiques topographiques détaillées et vue d'ensemble de la face est (en haut à droite, en 2007). Les flèches indiquent la zone de détachement de la grande avalanche de glace de 2005. La largeur de la zone de cassure est d'environ $120 \mathrm{~m}$, la profondeur détachée du glacier d'environ 15 à $30 \mathrm{~m}$. Ces changements de grande taille - ainsi que des occurrences plus petites - peuvent être identifiés et mesurés en utilisant le LIDAR.

Photos: J. VAllet, L. Fischer; GeoBasisDaten: ( BSF Swissphoto

failure (FAilLETTAZ et al. 2008). If these first measurements are confirmed in the future and if local employment of instruments is feasible, a seismic monitoring at critical locations could considerably improve early warning efforts.

\section{Investigations on rock-ice avalanche mobility}

Propagation and mobility of rock-ice avalanches ultimately determine the extent of destruction. The moving avalanche volume is a major control factor 
of avalanche mobility and depends both on the initial failure volume and on possible entrainment and deposition processes along the trajectory (LEgros 2002; Mangeney et al. 2007). Topography is another important factor influencing the reach and extent of the avalanche (Griswold \& IVERSON 2007; OKURA et al. 2003).

In densely developed and populated mountain regions as the Swiss Alps more precise information on the travel distance and trajectory can be very helpful for planning and hazard management purposes.

The area overrun by the avalanche, and thus the potential extent of damage, is related to the mobility of the mass movement. The angle of reach of the avalanche (also termed Fahrböschung or average slope), expressed by the ratio of vertical drop to horizontal runout distance, is a simple and useful concept to assess the mobility. This concept was originally introduced by Негм (1932) and since then has been widely applied for different types of mass movements, including small to large landslides, debris and rock avalanches (COROMINAS 1996; HsÜ 1975), debris flows (Haeberli et al. 1990; Huggel et al. 2004; RicKenMANN \& ZimMERMANN 1993), ice avalanches (Alean 1985; SAlZMANN et al. 2004) or glacier lake outburst floods (HAeberLi 1983; Huggel et al. 2003). Several empirical equations have been proposed to relate the angle of reach with the volume of landslides and rockice avalanches (e.g. Evans \& Clague 1988; Legros 2002; SCHEIDEGGER 1973).

For the propagation and runout of rapid mass movements a considerable range of models have been developed. Several of them are able to adjust to a range of different types of mass movements, e.g. rock, debris and ice avalanches or debris flows. The objective of the application of such models can be (i) improving the understanding of the mass movement dynamics, typically by retrospective modelling of case studies, and/or (ii) delineating areas potentially affected by defining and applying different failure and avalanche propagation scenarios. The definition of the scenario, including the failure volume, is a critical part of any such hazard assessment and often fraught with considerable uncertainty.

Models that have a more explicit physical basis tend to require input and calibration parameters that are not always easily available, and need more computational resources. They are typically applied to specific case studies. For rock or combined rock-ice avalanches for example DAN/DAN3D (Evans et al. 2009; McDouGALL \& HUNGR 2004), TITAN2D (PITMAN et al. 2003) or RAMMS (RApid Mass MovementS) (CHRISTEN et al. 2010) have been applied. Earlier applications for ice avalanches in the Alps have used 1D models based on Voellmy-Salm friction terms (AlEAN 1985; MARGRETH \& FunK 1999).

Models that use hydrologic flow algorithms to propagate a moving mass downstream typically have the advantage of a limited number of input information required, fast computation, integration in GIS environments and potential application over large areas. The level of resulting information usually corresponds best with the objectives of rapid first-order assessments. For ice and rock avalanches, applications have been demonstrated for several mountain ranges, including the Alps or Alaska (Huggel et al. 2007; Noetzli et al. 2006; SALZMANN et al. 2004).

Several combined rock-ice avalanche events have indicated that the presence of ice has an important effect on the flow dynamics, and therefore, on the areas affected (e.g. Erismann \& Abele 2001; Evans \& Clague 1988; HugGel et al. 2005). However, the role of ice still remains to be systematically assessed and quantified. Therefore, in a research collaboration between the University of Zurich and the Swiss Federal Institute for Forest, Snow and Landscape Research WSL-SLF the influence of ice on the mobility of ice-rock avalanches is now being investigated in detail. The underlying hypothesis is that ice has an effect on the friction of rapid mass movements as parameterized in numerical flow models, essentially through the physical properties of ice and related phase transitions.

A compilation of information on recent and historical rock-ice avalanches is used to document and analyze the characteristics of such events. Existing computer models (mainly the RAMMS model developed by WSL-SLF) are applied while the model parameters are adjusted for reasonably simulating such avalanches (Allen et al. 2009). RAMMS is also capable of modelling erosion along the flow trajectory, which is an important process in large mass movements and enables much more realistic simulations. Actually, erosive processes during the avalanche motion are especially important where the trajectory leads across easily erodible surfaces such as snow, firn or loose debris. If the amount of eroded material strongly contributes to the avalanche volume, the travel distance and impact of the avalanche can be enhanced significantly. Figure 3 shows a retrospective simulation of the 1997 Brenva rock avalanche in the Mont Blanc region, Italy. Two people were killed by this event, and the avalanche stopped at relatively close distance to the major international transit route of the Mont Blanc tunnel.

In addition to the event analysis and numerical modelling, laboratory experiments with rotating drums were performed in a $2.4 \mathrm{~m}$ diameter drum at the 


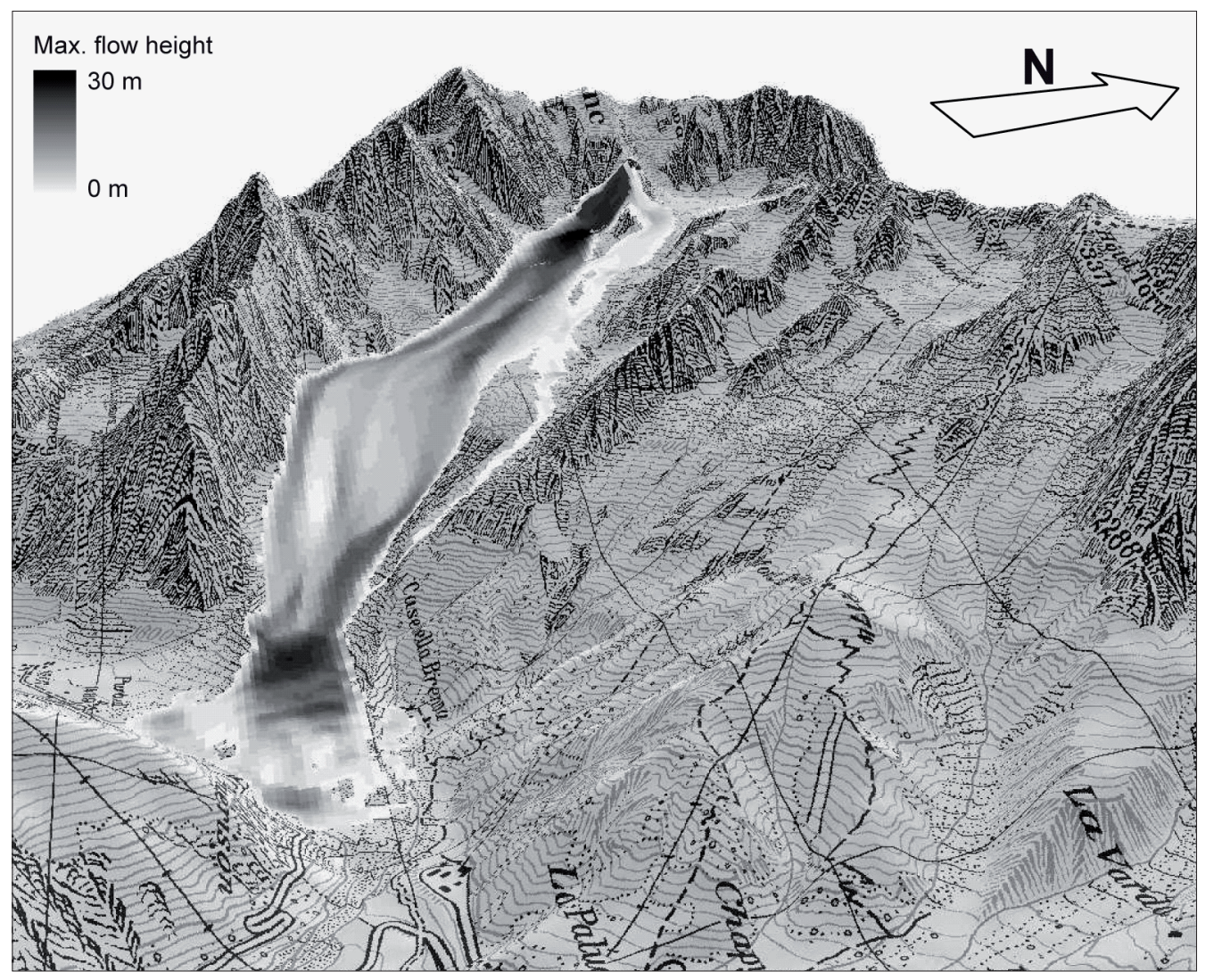

Fig. 3: Simulation using the RAMMS model of the 1997 Brenva rock-ice avalanche that entrained significant amounts of snow. The avalanche killed two skiers and hit some small tracks. Note the close distance to the international transit route of the Mont Blanc tunnel in the foreground of the image.

Simulation der Brenva Fels-Eislawine 1997 mit dem RAMMS-Modell. Die Lawine hat grosse Mengen Schnee mitgerissen, zwei Skifahrer getötet und kleinere Wege getroffen. Beachtet werden sollte die kurze Distanz vom Auslaufgebiet der Lawine zum Terminal der wichtigen internationalen Transitroute am Mt. Blanc-Tunnel im Vordergrund.

Simulation de l'avalanche de glace et de rochers de la Brenva de 1997 à l'aide du modèle RAMMS. En entraînant de grandes quantités de neige, cette avalanche a tué deux skieurs et coupé plusieurs chemins. A noter la courte distance séparant cette avalanche de l'axe de transit international du tunnel du Mont Blanc, visible en arrière-plan de l'image.

Reproduced by permission of swisstopo (BA081843)

BOKU University in Vienna and were complemented in a $4 \mathrm{~m}$ diameter drum at the National Center for Earth-surface Dynamics (NCED) at the University of California, Berkeley, to physically quantify the influence of ice on flow dynamics. The experimental setup in a rotating drum enables simulation of very long flow process durations (e.g. 30 minutes or longer), compared to chute flumes $(<1$ minute). Flow transformation from a dry cold rock-ice mixture to a highly mobile debris flow can be well observed and measured. Continuous measurement of shear and normal forces can be used to calculate the basal friction coefficients while pore water pressure measurements are used to analyse the influence of the increasing water content due to melting ice. Preliminary evaluation of the drum experiments suggests a strong influence of the ice on mobility as a continuous supplier of water due to friction and interaction with ground and air 


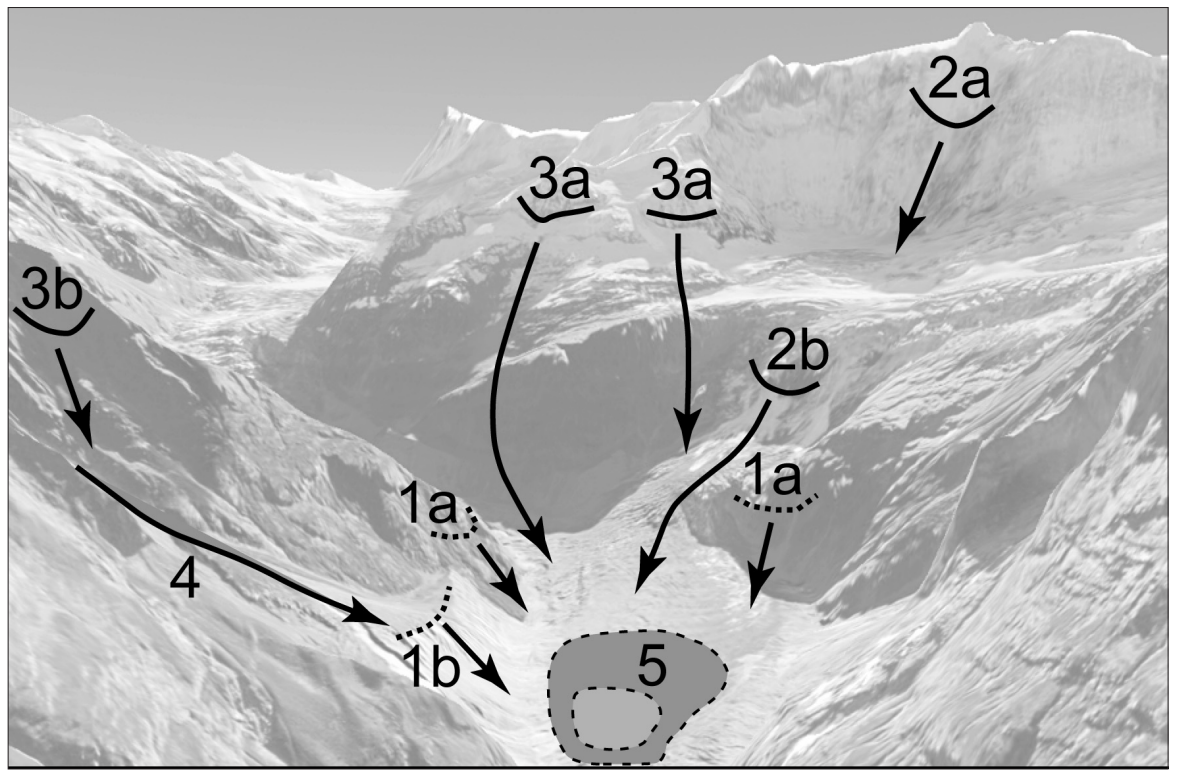

Fig. 4: An integrative perspective on different high-mountain mass movement hazards and their interaction under impact of climate change (adapted from the situation at Lower Grindelwald glacier, Switzerland). Landslide in bedrock (1a) and moraine (1b) due to debuttressing effects from glacier retreat since the Little Ice Age. Ice avalanches from polythermal steep glaciers due to increasing firn and ice temperatures (2a), and from dissected temperate steep glacier parts (2b). Rock fall and avalanches due to permafrost degradation (3a). Regular rock fall from areas of warm bedrock permafrost (3b) fuelling debris flow (4) initiation zones. Lake formation (5) due to glacier retreat, posing outburst floods hazards that are exacerbated by potential impact from multiple mass movement processes.

Eine integrierte Perspektive auf verschiedene Massenbewegungsgefahren im Hochgebirge und entsprechende Prozessinteraktionen unter dem Einfluss des Klimawandels (der Situation am Unteren Grindelwaldgletscher angepasst). Hanginstabilitäten im Fels (1a) und Moräne (1b) aufgrund von Druckentlastungseffekten durch Gletscherrückzug seit der Kleinen Eiszeit. Eislawinen von polythermalen steilen Gletschern in Beziehung mit steigenden Firn- und Eistemperaturen (2a) und von abgetrennten temperierten Gletscherpartien (2b). Felsstürze aus Gebieten mit warmem Permafrost (3b), als Zulieferer für Murganganrisszonen (4). Seenbildung (5) infolge Gletscherrückzugs kann zu Flutgefahren führen, die zusätzlich durch mögliche Einwirkungen aufgrund der verschiedenen Massenbewegungen verstärkt werden.

Perspective intégrée de différents dangers naturels liés à des mouvements de masse en haute montagne ainsi que leurs interactions sous l'impact du changement climatique (adapté de la situation du Bas Glacier de Grindelwald). Glissements de terrain sur roche (1a) et moraine $(1 b)$ dus à la décompression provoquée par le retrait glaciaire observé depuis le Petit Âge glaciaire. Avalanche de glace en provenance de glaciers suspendus en relation avec l'augmentation des températures des névés et de la glace (2a), et venant de parties réchauffées de glaciers suspendus (2b). Chute de rochers et avalanches en relation avec la dégradation du pergélisol (3a). Chute de rochers régulière en provenance de pergélisols réchauffés $(3 b)$, alimentant le flux de débris issu des zones de détachement (4). Formation de lacs de retenue (5) pouvant se rompre et dont les dangers sont exacerbés par l'impact potentiel de multiples processus liés aux mouvements de masse.

temperatures above $0^{\circ} \mathrm{C}$. The mechanical effect of the granular ice in the moving mass further reduces friction significantly. Parameterization of mechanical (coefficients of friction, flow depths, velocity profiles, flow densities) and dynamic properties (flow transfor- mations, evolution of the frictional characteristics and temperature) of varying debris-ice mixtures should help for a systematic analysis and an improvement of the understanding of processes effective in rock-ice mixtures. 


\section{Conclusions}

Recent large slope failures in ice and rock in glacier and permafrost environments in the Alps and other cold mountain areas could be an indication of climatically induced slope destabilization. Many of the factors involved are, however, difficult to assess, both on a local and regional level. On a rough level, some firstorder indications on susceptibility to slope failure may be provided considering topography, basic geological setting, permafrost and glacier changes. For more specific assessments more in-depth investigations on the integrated effect of different factors on slope stability are needed. For instance, ongoing research projects investigating hydro-thermal-mechanical processes on a small-scale could help improving the related understanding (HASLER et al. 2008).

Improved assessment of critical instability zones allows to better constrain flow propagation and runout models which in turn improves hazard mapping. Furthermore, on this scale, interaction and cascades of processes become important, especially concerning mass movements impacting natural or artificial lakes in high mountains (Fig. 4). The possibility of severe cases such as a major rock-ice avalanche into an already existing or newly forming lake with corresponding impact wave and flood hazard can not be excluded: the insufficient understanding of instability and failure, therefore, underlines the importance of intensified research and the development of consistent and long-term monitoring, prevention and early warning strategies.

\section{Acknowledgements}

Some of the studies described here were supported by the Swiss National Science Foundation, projects no. 200021-111967, and 200021-121823/1. The photogrammetric studies at the Monte Rosa were a cooperation of the University of Zurich with ETH Zurich (H. Eisenbeiss) and the University of Oslo (A. Kääb). The research project on the influence of ice on the mobility of rock-ice avalanches is a collaboration with the Swiss Federal Institute for Forest, Snow and Landscape Research WSL-SLF (B. McArdell, P. Bartelt).

\section{References}

AlEAN, J. (1985): Ice avalanches: some empirical information about their formation and reach. - In: Journal of Glaciology 31, 109: 324-333.

Allen, S.K., Schneider, D. \& I.F. Owens (2009): First approaches towards modelling glacial hazards in the Mount Cook region of New Zealand's Southern Alps. - In: Natural Hazards and Earth System Sciences 9: 481-499.
Allen, S., Cox, S. \& I. Owens: Rock-avalanches and other landslides in the central Southern Alps of New Zealand: a regional assessment of possible climate change impacts. - In: Landslides (in press).

Barla, G., Dutto, F. \& G. Mortara (2000): Brenva glacier rock avalanche of 18 January 1997 on the Mont Blanc range, Northwest Italy. - In: Landslide News 13: 2-5.

Bottino, G., Chiarle, M., Joly, A. \& G. Mortara (2002): Modelling rock avalanches and their relation to permafrost degradation in glacial environments. - In: Permafrost and Periglacial Processes 13, 4: 283288.

CAPlan-Auerbach, J. \& C. Huggel (2007): Precursory seismicity associated with frequent, large avalanches on Iliamna Volcano, Alaska. - In: Journal of Glaciology 53, 180: 128-140.

Chen, R.-F., Chang, K.-J., Angeliera, J., Chan, Y.C., Deffontaines, B., Lee, C.-T. \& M.-L. Lin (2006): Topographical changes revealed by high-resolution airborne LiDAR data: the 1999 Tsaoling landslide induced by the Chi-Chi earthquake. - In: Engineering Geology 88: 160-172.

Christen, M., Bartelt, P. \& J. Kowalski (2010): Back calculation of the In den Arelen avalanche with RAMMS: interpretation of model results. - In: Annals of Glaciology 51, 54: 161-168.

Cola, G. (2005): La grande frana della cresta Sud-Est della Punta Thurwieser (Thurwieser-Spitze) $3658 \mathrm{~m}$ (Alta Valtellina, Italia). - In: Terra Glacialis 8: 38-45.

Corominas, J. (1996): The angle of reach as a mobility index for small and large landslides. - In: Canadian Geotechnical Journal 33, 2: 260-271.

Cruden, D.M. \& D.J. Varnes (1996): Landslide types and processes. - In: Turner, A.K. \& R.L. Schuster (eds): Landslides, investigation and mitigation. - Washington, D.C.: National Acadamy Press: 36-75.

Diotri, F., Roncella, R., Forlani, G., Lucianaz, C., VAgLiasindi, M., BRocherel, D. \& J.P. Fosson (2009): Efficient surveying of hanging glaciers: the serac of the Grandes Jorasses. - International Workshop on Glacier, Permafrost and GLOF Hazards, 10-12 November 2009, Vienna (abstract).

ERISMANN, T.H. \& G. Abele (2001): Dynamics of rockslides and rockfalls. - Heidelberg: Springer.

Evans, S.G. \& J.J. Clague (1988): Catastrophic rock avalanches in glacial environments. - In: BONNARD, C. (ed.): Landslides. - Proceedings of the $5^{\text {th }}$ International Symposium on Landslides, 10-15 July 1988, Lausanne, Switzerland: 1153-1158.

Evans, S.G. \& J.J. Clague (1994): Recent climatic change and catastrophic geomorphic processes in mountain environments. - In: Geomorphology 10, 1-4: 107-128.

Evans, S.G., Tutubalina, O.V., Drobyshev, V.N., Chernomorets, S.S., McDougall, S., Petrakov, D.A. \& O. HUNGR (2009): Catastrophic detachment and high- 
velocity long-runout flow of Kolka Glacier, Caucasus Mountains, Russia in 2002. - In: Geomorphology 105, 3-4:314-321.

Faillettaz, J., Pralong, A., Funk, M. \& N. DeichMANN (2008): Evidence of log-periodic oscillations and increasing icequake activity during breaking-off of large ice masses. - In: Journal of Glaciology 54, 187 . 725-737.

Fischer, L. (2009): Slope instabilities on perennially frozen and glacierised rock walls: multiscale observation, analyses and modelling. - PhD thesis, Faculty of Science, University of Zurich.

Fischer, L., Kä̈̈B, A., Huggel, C. \& J. NoetZli (2006): Geology, glacier retreat and permafrost degradation as controlling factors of slope instabilities in a high mountain rock wall: the Monte Rosa east face. - In: Natural Hazards and Earth System Science 6: 761-772.

Fischer, L. \& C. Huggel (2008): Methodical design for stability assessments of permafrost affected highmountain rock walls. - In: Proceedings of the $9^{\text {th }}$ International Conference on Permafrost, 29 June-3 July, 2008, Fairbanks, Vol. 1: 439-444.

Fischer, L., Eisenbeiss, H., Kä̈̈в, A., Huggel, C. \& W. HAEBerli: Detecting topographic changes in steep high-mountain flanks using combined repeat airborne LIDAR and aerial optical imagery - a case study on climate-induced hazards at Monte Rosa east face, Italian Alps. - In: Permafrost and Periglacial Processes (submitted).

Griswold, J.P. \& R.M. IvERSON (2007): Mobility statistics and automated hazard mapping for debris flows and rock avalanches. - USGS Scientific Investigations Report 5276, Reston, Virginia.

Gruber, S. \& W. Haeberli (2007): Permafrost in steep bedrock slopes and its temperature-related destabilization following climate change. - In: Journal of Geophysical Research 112, F02S18, doi:10.1029/ 2006JF000547.

HAEBERLI, W. (1983): Frequency and characteristics of glacier floods in the Swiss Alps. - In: Annals of Glaciology 4: 85-90.

Haeberli, W., Alean, J.C., Müller, P. \& M. FunK (1989): Assessing risks from glacier hazards in high mountain regions: some experiences in the Swiss Alps. - In: Annals of Glaciology 13: 96-102.

Haeberli, W., Rickenmann, D. \& M. Zimmermann (1990): Investigation of 1987 debris flows in the Swiss Alps: general concept and geophysical soundings. - In: Hydrology of Mountainous Regions II: Artificial Reservoirs, Water and Slopes. IAHS Publication 194: 303310.

HAEBERLI, W. (2005): Investigating glacier-permafrost relationships in high-mountain areas: historical background, selected examples and research needs. - In: Harris, C. \& J.B. Murton (eds): Cryospheric systems: glaciers and permafrost. - The Geological Society of London, Special Publication 242: 29-37.
Haeberli, W., Huggel, C., Kä̈̈в, A., Gruber, S., Noetzli, J. \& S. Zgraggen-Oswald (2006): Development and perspectives of applied research on glacier and permafrost hazards in high-mountain regions - the example of Switzerland. - In: Proceedings of the International Conference on High Mountain Hazard Prevention, Vladikavkaz/Moscow, June 23-26, 2004: 219-228.

Haeberli, W., Huggel, C., Kä̈̈в, A., ZgraggenOswald, S., Polkvou, A., Galushrin, I., Zotikov, I. \& N. OsoKIN (2004): The Kolka-Karmadon rock/ice slide of 20 September 2002: an extraordinary event of historical dimensions in North Ossetia, Russian Caucasus. - In: Journal of Glaciology 50, 171: 533-546.

Haeberli, W., Wegmann, M. \& D. Vonder Muehll (1997): Slope stability problems related to glacier shrinkage and permafrost degradation in the Alps. - In: Eclogae Geologicae Helvetiae 90: 407-414.

Haefeli, R. (1966): Note sur la classification, le mécanisme et le contrôle des avalanches de glaces et des crues glaciaires extraordinaires. - In: International Association of Hydrological Sciences (IAHS), Publication 69: 316-325.

Hasler, A., Talzi, I., Beutel, J., Tschudin, C. \& S. GRUBER (2008): Wireless sensor networks in permafrost research - concept, requirements, implementation and challenges. - In: Proceedings of the $9^{\text {th }}$ International Conference on Permafrost, 29 June-3 July, 2008, Fairbanks, Alaska, USA: 669-674.

Heim, A. (1932): Bergsturz und Menschenleben. - Beiblatt zur Vierteljahrschrift der Naturforschenden Gesellschaft in Zürich 77.

Hsü, K.J. (1975): Catastrophic debris streams (sturzstroms) generated by rockfalls. - In: Geological Society of America Bulletin 86,1:129.

Huggel, C. (2009): Recent extreme slope failures in glacial environments: effects of thermal perturbation. - In: Quaternary Science Reviews 28, 11-12: 11191130.

Huggel, C., KäÄв, A., Haeberli, W. \& B. KrummenACHER (2003): Regional-scale GIS-models for assessment of hazards from glacier lake outbursts: evaluation and application in the Swiss Alps. - In: Natural Hazards and Earth System Sciences 3, 6: 647-662.

Huggel, C., Haeberli, W., Kä̈̈в, A., Bieri, D. \& S. RICHARDSON (2004): An assessment procedure for glacial hazards in the Swiss Alps. - In: Canadian Geotechnical Journal 41, 6: 1068-1083.

Huggel, C., Zgraggen-Oswald, S., Haeberli, W. KäÄв, A., Polkvoj, A., Galushrin, I. \& S.G. Evans (2005): The 2002 rock-ice avalanche at Kolka/Karmadon, Russian Caucasus: assessment of extraordinary avalanche formation and mobility, and application of QuickBird satellite imagery. - In: Natural Hazards and Earth System Sciences 5:173-187.

Huggel, C., Caplan-Auerbach, J., Waythomas, C.F. \& R.L. Wessels (2007): Monitoring and modeling 
ice-rock avalanches from ice-capped volcanoes: a case study of frequent large avalanches on Iliamna Volcano, Alaska. - In: Journal of Volcanology and Geothermal Research 168, 1-4: 114-136.

Huggel, C., Caplan-Auerbach, J. \& R. Wessels (2008): Recent extreme avalanches: triggered by climate change? - In: EOS, Transactions, American Geophysical Union 89, 47: 469-470.

Jibson, R.W., Harp, E.L., Schulz, W. \& D.K. Keefer (2006): Large rock avalanches triggered by the M 7.9 Denali Fault, Alaska, earthquake of 3 November 2002. - In: Engineering Geology 83, 1-3: 144-160.

KӓÄв, A. (1996): Photogrammetrische Analyse zur Früherkennung gletscher- und permafrostbedingter Naturgefahren im Hochgebirge. - Mitteilungen 145, Versuchsanstalt für Wasserbau, Hydrologie und Glaziologie, ETH Zürich.

Kä̈̈в, A., Reynolds, J.M. \& W. Haeberli (2005): Glacier and permafrost hazards in high mountains. - In: Huber, U.M., Burgmann, H.K.H. \& M.A. Reasoner (eds): Global change and mountain regions (a state of knowledge overview). - Dordrecht: Springer: 225-234. KeEfer, D.K. (2002): Investigating landslides caused by earthquakes - a historical review. - In: Surveys in Geophysics 23, 6: 473-510.

Legros, F. (2002): The mobility of long-runout landslides. - In: Engineering Geology 63, 3-4: 301-331.

Mangeney, A., Tsimring, L.S., Volfson, D., Aranson, I.S. \& F. Bouchut (2007): Avalanche mobility induced by the presence of an erodible bed and associated entrainment. - In: Geophysical Research Letters 34 (L22401).

Margreth, S. \& M. FunK (1999): Hazard mapping for ice and combined snow/ice avalanches - two case studies from the Swiss and Italian Alps. - In: Cold Regions Science and Technology 30,1-3:159-173.

McDougall, S. \& O. Hungr (2004): A model for the analysis of rapid landslide motion across three-dimensional terrain. - In: Canadian Geotechnical Journal 41, 6: 1084-1097.

Noetzli, J., Huggel, C., Hoelzle, M. \& W. Haeberli (2006): GIS-based modelling of rock-ice avalanches from Alpine permafrost areas. - In: Computational Geosciences 10: 161-178, doi: 10.1007/s10596-005-9017z.

Noetzli, J., Gruber, S., Kohl, T., Salzmann, N. \& W. HAEBERLI (2007): Three-dimensional distribution and evolution of permafrost temperatures in idealized high-mountain topography. - In: Journal of Geophysical Research 112 (F2): F02S13.

Noetzli, J. \& S. Gruber (2009): Transient thermal effects in Alpine permafrost. - In: The Cryosphere 3: 85-99.

Okura, Y., Kitahara, H., Kawanami, A. \& U. Kurokawa (2003): Topography and volume effects on travel distance of surface failure. - In: Engineering Geology 67, 3-4: 243.

OpPikOFER, T., JABOYedoff, M. \& H.-R. KeUSEN (2008):
Collapse at the eastern Eiger flank in the Swiss Alps. - In: Nature Geoscience 1:531-535.

Pitman, E.B., Nichita, C.C., Patra, A., Bauer, A., Sheridan, M. \& M. BursiK (2003): Computing granular avalanches and landslides. - In: Physics of Fluids 15, 12: 3638-3646.

Pralong, A. \& M. FunK (2005): On the instability of hanging glaciers. - In: Journal of Glaciology 52: 31-48.

Ravanel, L., Allignol, F., Deline, P., Gruber, S. \& M. Ravello (2010): Rock falls in the Mont Blanc Massif in 2007 and 2008. - In: Landslides (in press).

Rickenmann, D. \& M. Zimmermann (1993): The 1987 debris flows in Switzerland: documentation and analysis. - In: Geomorphology 8, 2-3: 175-189.

RöTHLISBERger, H. (1987): Sliding phenomena in a steep section of Balmhorngletscher, Switzerland. - In: Journal of Geophysical Research 92 (B9): 8999-9014.

Salzmann, N., Kä̈̈B, A., Huggel, C., Allgöwer, B. \& W. Haeberli (2004): Assessment of the hazard potential of ice avalanches using remote sensing and GISmodelling. - In: Norsk Geografisk Tidsskrift 58, 2: 7484.

ScheIdegGer, A.E. (1973): On the prediction of the reach and velocity of catastrophic landslides. - In: Rock Mechanics and Rock Engineering 5, 4:231-236. Suter, S. (2002): Cold firn and ice in the Monte Rosa and Mont Blanc areas: spatial occurrence, surface energy balance and climatic evidence. - PhD thesis, Laboratory of Hydraulics, Hydrology and Glaciology (VAW), Swiss Federal Institute of Technology (ETH) Zurich.

Wieczorek, G.F. \& T. Glade (2005): Climatic factors influencing occurrence of debris flows. - In: ЈАКОВ, M. \& O. HungR (eds): Debris-flow hazards and related phenomena. - Berlin, Heidelberg: Springer: 325-362.

Zimmermann, M., Mani, P. \& H. Romang (1997): Magnitude-frequency aspects of alpine debris flows. - In: Eclogae Geologicae Helvetiae 90, 3: 415-420.

\section{Summary: Research advances on climate-induced slope instability in glacier and permafrost high- mountain environments}

High-mountain areas with glacier and permafrost occurrence are temperature sensitive environments. Climatic changes are, thus, likely to have an effect on slope stability. Several recent events have shown that rock and ice avalanches and related hazards can have severe consequences. For hazard analysis, the processes of slope failure and flow dynamics should therefore be better understood. In this article, recent advances in this field are presented, including high-resolution topographic monitoring of a large Alpine high-mountain flank (Monte Rosa) over the past 50 years and laboratory experiments with rotating drums and numerical modelling. This recent research has revealed important insight into the causes and dynamics of slope 
instabilities and contributes towards a better understanding of the influence of ice on avalanche dynamics and runout. It is emphasized that high-mountain slope failures need to be viewed from an interdisciplinary perspective, taking a number of process interactions into account.

Keywords: rock-ice avalanche, glacier, permafrost, hazards

\section{Zusammenfassung: Neue Forschungsresultate zu klimabedingten Hanginstabilitäten in glazialen und periglazialen Gebirgsregionen}

Hochgebirgsregionen mit Gletschern und Permafrost reagieren sensitiv auf Temperaturveränderungen. Klimaänderungen können entsprechend einen Einfluss auf die Hangstabilität ausüben. Verschiedene Ereignisse in den letzten Jahren haben bestätigt, dass Eis- und Felslawinen eine besonders zerstörerische Wirkung haben können. Die Prozesse im Zusammenhang mit Hanginstabilitäten und Lawinenausbreitung sollten deshalb besser verstanden werden. In dieser Studie werden neue Forschungsarbeiten präsentiert, die einerseits hoch aufgelöste topographische Messungen einer grossen vergletscherten Wand in den Alpen (Monte Rosa) über 50 Jahre umfassen und dabei wichtige Erkenntnisse über Ursachen und Zusammenhänge der Fels- und Eisstürze erlauben. Andererseits wurden Laborexperimente und numerische Modellierungen von Lawinen durchgeführt, um den Einfluss von Eis auf die Lawinendynamik und -ausbreitung zu verstehen. Die Studie macht klar, dass die Gefahrenanalyse von Fels- und Eislawinen im Hochgebirge interdisziplinär angegangen werden muss mit einem besonderen Augenmerk auf Prozessinteraktionen.

Schlüsselwörter: Fels-Eislawine, Gletscher, Permafrost, Naturgefahren

\section{Résumé: Instabilités de pente liées au climat dans les environnements glaciaires et périglaciaires de haute montagne}

Les zones de haute montagne, caractérisées par des glaciers et du pergélisol, sont sensibles aux changements de température. Les changements climatiques sont par conséquent susceptibles d'avoir des effets sur la stabilité des pentes. Plusieurs événements récents ont montré que les avalanches de roche et de glace ainsi que les dangers naturels qui leur sont liés peuvent avoir des conséquences importantes. En matière d'analyse de dangers naturels, les processus de cassure de pente et de dynamique des flux devraient par conséquent être mieux compris. Cet article présente les développements récents dans le domaine, notamment un suivi topographique à haute résolution du versant d'une importante montagne alpine (le Mont Rose) depuis 50 ans, ainsi que des expérimentations en laboratoire à l'aide de tambours rotatifs et de modélisations numériques. Ce travail apporte des résultats importants relativement aux causes et aux dynamiques de l'instabilité des pentes et a contribué à une meilleure compréhension de l'influence de la glace dans les dynamiques des avalanches. En conclusion, l'article montre que les événements relatifs aux ruptures de pente nécessitent d'être considérés selon une perspective interdisciplinaire, qui prenne en considération un certain nombre d'interactions entre les processus à l'œuvre.

Mots-clés: avalanche de glace/roche, glacier, pergélisol, dangers naturels

Dr. Christian Huggel, Dr. Luzia Fischer, Dipl.-Geogr. Demian Schneider, Prof. Dr. Wilfried Haeberli, Glaciology, Geomorphodynamics and Geochronology, Department of Geography, University of Zurich, Winterthurerstrasse 190, CH-8057 Zürich, Switzerland. e-mail:

christian.huggel@geo.uzh.ch

luzia.fischer@geo.uzh.ch

demian.schneider@geo.uzh.ch

wilfried.haeberli@geo.uzh.ch

\section{Manuskripteingang/received/manuscrit entré le}

12.1.2010

Annahme zum Druck/accepted for publication/accepté pour l'impression: 11.7.2010 